\title{
Penerapan Metode Pembelajaran Problem Base Learning pada Bidang Ilmu Keteknikan (Engineering)
}

\author{
Nofirza $^{1}$, Harpito ${ }^{2}$, Ismu Kusumanto ${ }^{3}$ \\ 1,2,3 Jurusan Teknik Industri, Fakultas Sains dan Teknologi, UIN Sultan Syarif Kasim Riau \\ Jl. HR. Soebrantas No. 155 Simpang Baru, Panam, Pekanbaru, 28293 \\ Email: nofirza@uin-suska.ac.id, harpito@uin-suska.ac.id,ismu_uin@yahoo.co.id
}

\begin{abstract}
ABSTRAK
Kecenderungan mahasiswa bersikap pasif dalam perkuliahan mengakibatkan daya fikir analitis yang rendah dan mendapatkan nilai pembelajaran yang rendah merupakan salah satu dampak sistem pembelajaran dengan metode ceramah. Penelitian ini ditujukan untuk mengetahui pengaruh implementasi Lesson Study dengan metoda Problem Base Learning (PBL) dalam meningkatkan proses pembelajaran (keaktifan, kemampuan berfikir analitis dan skill keteknikan) dan hasil pembelajaran di bidang engineering. Penelitian ini bersifat kolaboratif-partisipatif dengan dosen-dosen mata kuliah dan melibatkan mahasiswa dengan langkah-langkah membentuk tim Lesson Study, merencanakan perkuliahan (plan), melaksanakan perkuliahan/observasi (do), dan refleksi/menganalisis hasil observasi dan mendiskusikan (See) yang dilakukan di Jurusan Teknik Industri UIN Suska Riau. Metode yang digunakan dalam penelitian ini adalah gabungan dari metoda kualitatif (proses pembelajaran) dengan metoda kuantitatif (hasil pembelajaran). Proses pembelajaran berupa aktivitas mahasiswa didapatkan dengan observasi, dokumentasi dan angket, sementara hasil pembelajaran berupa nilai mahasiswa didapatkan dengan tes. Melalui implementasi lesson study dengan metoda pembelajaran PBL, proses pembelajaran (keaktifan, kemampuan berfikir analitis dan skill keteknikan) dan hasil pembelajaran (nilai mahasiswa) mengalami peningkatan yang sgnifikan dengan nilai Gain yaitu 0,703 (kategori tinggi) dan nilai Sig. $<\alpha$ serta $t$ hitung $<-t$ tabel. Berdasarkan hasil ini diharapkan kedepannya lebih banyak lagi dosen yang menerapkan metode PBL sehingga mahasiswa lebih memiliki kemampuan analisis yang tinggi dan ketertarikan belajar yang lebih aktif.
\end{abstract}

Kata Kunci: Implementasi Lesson Study, Problem Base Learning

\section{Pendahuluan}

\section{Latar Belakang}

Dengan metoda pembelajaran sistem ceramah, dan bahan tayang yang banyak dipraktekkan saat ini, mahasiswa di Fakultas Sains dan Teknologi UIN Suska Riau cenderung bersikap pasif dan memiliki daya perfikir analitis yang rendah dalam proses pembelajaran. Hal ini berdampak pada nilai mahasiswa yang dapat dikategorikan rendah yaitu degan rata-rata IPK berkisar antara 2,80 s/d 2,90 serta skill keteknikan yang rendah pula. Untuk menyikapi hal tersebut, penulis merasa perlu dilakukan gebrakan dalam rangka mencari alternatif solusi untuk menggenjot kualitas proses pembelajaran berupa keaktifan, kemampuan berfikir analitis dan skill keteknikan serta nilai hasil pembelajaran mahasiswa di Fakultas Sains dan Teknologi UIN Suska Riau khususnya Jurusan Teknik Industri.

Salah satu alternatif perbaikan dalam upaya meningkatkan mutu proses dan hasil pembelajaran pembelajaran adalah dengan melakukan Lesson Study dalam pendidikan baik dari jenjang sekolah dasar sampai Universitas.
Sejak seabad yang lalu, Jepang telah mempraktekkan lesson study secara tekun dan terus menerus sebagai usaha peningkatan mutu pendidikan.

Implementasi Lessons Study dengan metoda pembelajaran Problem Base Learning menawarkan metoda pembelajaran yang aktif dan memberikan harapan bagi kita untuk bisa meningkatkan proses dan hasil pembelajaran.

\section{Lesson Study}

Prinsip-prinsip Lesson Study

Lesson Study merupakan suatu pendekatan peningkatan kualitas pembelajaran yang dilaksanakan oleh dosen secara kolaboratif, dengan langkah-langkah pokok merancang pembelajaran untuk mencapai tujuan, melaksanakan pembelajaran (plan), melaksanakan mengamati pelaksanaan pembelajaran tersebut (do), serta melakukan refleksi untuk mendiskusikan pembelajaran yang dikaji tersebut untuk bahan penyempurnaan dalam rencana pembelajaran berikutnya (see). Fokus utama pelaksanaan lesson study adalah aktivitas mahasiswa di kelas, dengan asumsi bahwa 
aktivitas mahasiswa tersebut terkait dengan aktivitas dosen selama mengajar di kelas.

\section{Pengertian dan Tahapan Lesson Study}

Lesson Study berasal dari jepang yaitu dari kata jugyokenkyu yang artinya suatu proses sistematik yang digunakan oleh guru-guru jepang untuk menguji keefektifan pengajarannya dalam rangka meningkatkan hasil pembelajaran. Lesson Study di Indonsia dapat diartikan sebagai model pembinaan (pelatihan) profesi pendidik melalui pengkajian pembelajaran secara kolaboratif dan berkelanjutan berlandaskan prinsip-prinsip kolegialitas dan mutual learning untuk membangun komunitas belajar.

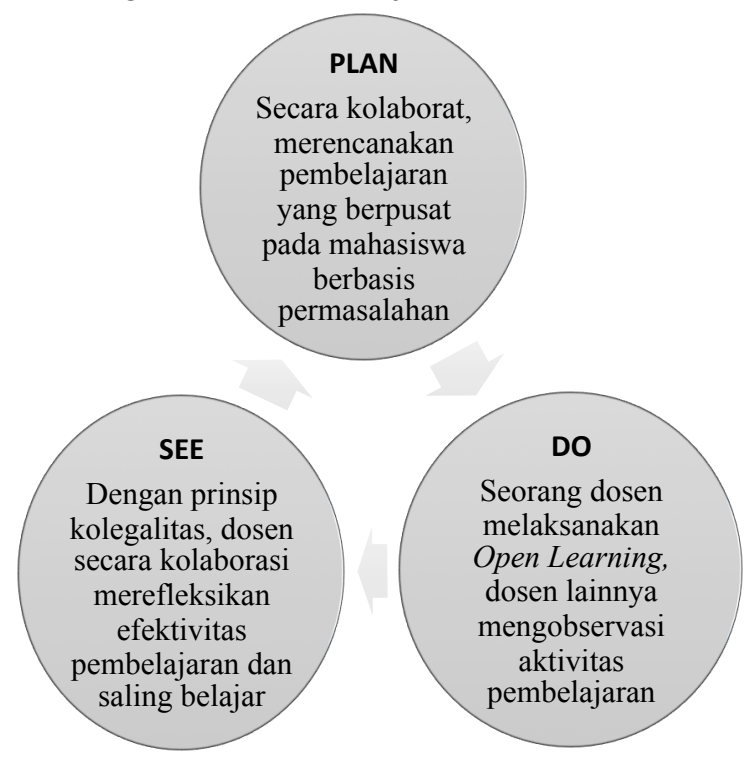

Gambar 1. Siklus Penggajian pembelajaran dalam Lesson Study

Hasil maksimal akan dapat diperoleh apabila ke tiga tahap di atas dilaksanakan secara utuh dan berkesinambungan. Melalui kegiatan Lesson Study ini kelemahan dosen model pada setiap tahap pembelajaran yang dilaksanakan dapat diperbaiki dan disempurnakan. Untuk lebih memudahkan pemahaman, tahapan tersebut di atas diilustrasikan pada bagan berikut:

\section{Problem Base Learning (PBL)}

\section{Pengertian Problem Base Learning}

Problem Base Learning merupakan metode pembelajaran yang mendorong peserta didik untuk mengenal cara belajar dan bekerjasama dalam kelompok untuk aktif mencari penyelesaian masalah-masalah di dunia nyata. Simulasi masalah digunakan untuk mengaktifkan keingintahuan peserta didik sebelum mulai mempelajari suatu subyek. . Problem Base Learning menyiapkan peserta didik untuk berpikir secara kritis dan analitis, serta mampu untuk mendapatkan dan menggunakan secara tepat sumber-sumber pembelajaran. Problem Base Learning merupakan sebuah model pembelajaran yang inovatif yang dapat memberikan suasana belajar aktif dan mandiri kepada peserta didik.

\section{Karakteristik Problem Base Learning}

Adapun karakteristik Problem Based

Learning adalah sebagai berikut:

1. Permasalahan menjadi starting point dalam belajar

2. Permasalahan yang diangkat adalah permasalahan yang ada di dunia nyata yang tidak terstruktur

3. Permasalahan memebutuhkan perspektif ganda

4. Permasalahan menantang pengetahuan yang dimilki oleh peserta didik, sikap dan kompentensi yang kemudian membutuhkan identifikasi kebutuhan belajar dan bidang baru dalam mengajar;

5. Belajar pengarahan diri menjadi hal yang utama:

6. Pemanfaatan sumber pengetahuan yang beragam, penggunaannya, dan evaluasi sumber informasi merupakan proses yang esensial dalam Problem Base Learning;

7. Belajar adalah kolaboratif, komunikasi, dan kooperatif;

8. Pengembangan keterampilan inquiri dan pemecahan masalah sama pentingnya dengan penguasaan isi pengetahuan untuk mencari solusi dari sebuah permasalahan;

9. Keterbukaan proses dalam Problem Base Learning meliputi sintesis dan integrasi dari sebuah proses belajar; dan

10. Problem Base Learning melibatkan evaluasi dan review pengalaman peserta didik dan proses belajar

\section{Sintak Model Problem Base Learning}

Proses Problem Base Learning mereplikasi pendekatan sistematik yang sudah banyak digunakan dalam menyelesaikan masalah atau memenuhi tuntutan-tuntutan dalam dunia kehidupan dan karier.

Sintak operasional Problem Base Learning bisa rmencakup antara lain sebagai berikut:

1. Peserta didik disajikan suatu masalah.

2. Peserta didik mendiskusikan masalah dalam tutorial Problem Base Learning dalam sebuah kelompok kecil.

3. Peserta didik terlibat dalam studi independen untuk menyelesaikan masalah diluar bimbingan dosen.

4. Peserta didik kembali pada tutorial PBL, lalu saling sharing, informasi, melalui peer 
teaching atau cooperative learning atas masalah tertentu.

5. Peserta didik menyajikan solusi atas masalah.

6. Peserta didik mereview apa yang mereka pelajari proses pengerjaan selama ini.

\section{Langkah-Langkah Penggunaan Model Problem Base Learning}

Langkah-langkah operasional dalam proses pembelajaran metoda pembelajaran Problem Base Learning yang dikonsepkan oleh Kementerian Pendidikan dan Kebudayaan Rebuplik Indonesia adalah sebagai berikut:

1. Konsep Dasar (Basic Concept)

2. Pendefinisian Masalah (Defining The Problem)

3. Pembelajaran Mandiri (Self Learning)

4. Pertukaran Pengetahuan (Exchange Knowledge)

5. Penilaian (Assessment)

\section{Bidang Keteknikan (Engineering) Pengertian Keteknikan}

Ilmu teknik merupakan ilmu yang mempelajari pengetahuan dan keterampilan untuk mentransformasi sumber daya (resource) dalam rangka melayani kebutuhan manusia dalam jumlah yang besar.

\section{Aspek Ilmu Keteknikan}

Ilmu teknik dapat ditinjau dari sudut pandang secara internal dan eksternal secara internal, ilmu teknik memiliki 3 aspek :

1. Sains keteknikan

2. Desain teknik pengembangan

3. Manajemen dan organisasi

Secara eksternal, bidang teknik berhubungan dekat dengan ilmu alam di satu pihak dan industri di pihak lain. Bersama-sama, ketiganya membentuk bidang teknologi.

\section{Inti Bidang IlmKeteknikan}

Untuk mendesain sistem yang berbasis teknologi, insinyur harus menguasai pengetahuan dan kepakaran baik secara global maupun detil di bidang yang sangat beragam.

\section{Metodologi}

\section{Metoda Penentuan Subjek Penelitian \\ Desain Penelitian}

Penelitian ini merupakan penelitian dengan Lessons Study yang bersifat kolaboratifpartisipatif dengan dosen-dosen mata kuliah dan melibatkan mahasiswa. Kegiatan Lessons Study ini menggunakan metoda pembelajaran Problem Base Learning yang merupakan gabuangan dari
PBL Indoor dan PBL Outdoor. Implementasi Lesson Study dilaksakan dalam tiga siklus yaitu Plan (merencanakan), Do (melaksanakan), dan See (merefleksi) dengan langkah-langkah sebagai berikut:

1. Membentuk kelompok atau tim Lesson Study

a. Dosen Model (pelaksana)

b. Dosen Observer (Kolaborasi)

2. Merencanakan perkuliahan/pembelajaran (plan)

3. Melaksanakan perkuliahan atau observasi (do)

4. Refleksi/ Menganalisis Hasil Observasi dan Mendiskusikan (See)

\section{Lokasi dan Waktu Penelitian}

Penelitian ini dilaksanakan pada mahasiswa semester III (Ganjil) Tahun Ajaran 2016/2017 kelas IIIB Matakuliah Mekanika Teknik Jurusan Teknik Industri Fakultas Sains dan Teknologi UIN Sultan Syarif Kasim Riau yang beralamat di Jl. HR. Soebrantas Km. 15 No. 155 Kecamatan Tampan, Kota Pekanbaru, Propinsi Riau.

\section{Populasi dan Sampel}

Populasi yang digunakan dalam penelitian ini adalah mahasiswa semester Ganjil (semester III) Jurusan Teknik Industri. Sampel yang digunakan adalah mahasiswa pada Mata Kuliah Mekanika Teknik sebanyak 1 kelas yaitu kelas IIIB yang berjumlah 25 mahasiswa sebagai fokus Lesson Study.

\section{Variabel Penelitian}

Variabel dalam penelitian ini ada dua yaitu variabel predikator (variabel bebas) dan variabel kriterium (variabel terikat). Variabel bebasnya adalah implemementasi Lesson Study pada pembelajaran Mekanika Teknik dengan metoda Problem Based Learning. Variabel terikatnya adalah kualitas proses dan hasil pembelajaran Mekanika Teknik.

\section{Pengumpulan Data}

Metode yang digunakan dalam penelitian ini adalah gabungan dari metoda kualitatif dengan metoda kuantitatif.

1. Aktivitas Mahasiswa
a. Metode observasi
b. Metode dokumentasi
c. Metode Angket

2. Hasil belajar mahasiswa

Metoda yang digunakan dalam megumpulkan data hasil belajar mahasiswa adalah metoda tes. 


\section{Analisis Data \\ Uji Peningkatan}

Untuk melihat peningkatan kualitas hasil pembelajaran mahasiswa dilakukan melalui analisis terhadap skor gain ternormalisasi $\langle g\rangle$ untuk kemudian dibandingkan dengan kategori yang dikemukakan oleh Hake (1999). Skor gain ternormalisasi yaitu perbandingan skor gain aktual dengan skor gain maksimum. Skor gain aktual yaitu skor gain yang diperoleh mahasiswa sedangkan skor gain maksimum yaitu skor gain tertinggi yang mungkin diperoleh mahasiswa. Menurut Hake (1998) Nilai skor gain $\langle g\rangle$ dapat dihitung dengan rumus berikut:

$$
\langle g\rangle=\frac{\left(S_{\text {Posttest }}-S_{\text {Pretest }}\right)}{S_{\text {max }}-S_{\text {Pretset }}} \times 100 \%
$$

Besarnya skor $\langle g\rangle$ dikategorikan Hake (1999) sebagai berikut :

Tinggi : $\langle g\rangle \geq 0,7$

Sedang : $0,3 \leq\langle g\rangle<0,7$

Rendah : $\langle g\rangle<0,3$

\section{Uji Hipotesis}

Uji hipotesis yang digunakan dalam penelitian ini adalah uji hipotesis dengan metoda paired sample $t$ test. Metoda ini digunakan karena data sampel dalam penelitian ini melibatkan pengukuraan pada subjek yang sama terhadap suatu pegaruh atau perlakuan tertentu.

Adapun langkah-langkah pengujiannya adalah sebagai berikut:

1. Menentukan $\mathrm{H}_{\mathrm{o}}$ dan $\mathrm{H}_{\mathrm{a}}$

$\mathrm{H}_{\mathrm{o}}$ : Melalui implementasi Lesson Study tidak ada peningkatan kualitas pembelajaran mahasiswa.

$\mathrm{H}_{\mathrm{o}}: \mathrm{U}_{1}-\mathrm{U}_{2}=0$

$\mathrm{H}_{\mathrm{a}}$ : Melalui implementasi Lesson Study terdapat peningkatan kualitas

pembelajaran mahasiswa.

$\mathrm{H}_{\mathrm{a}}: \mathrm{U}_{1}-\mathrm{U}_{2} \neq 0$

2. Menentukan level of significance

Dalam penelitian ini ditentukan taraf keyakinan dan tingkat toleransi kesalahan ( $\alpha$ $=0,05$ )

3. Kriteria Pengujian

$\mathrm{H}_{\mathrm{o}} \quad$ diterima jika $-t\left(\frac{\alpha}{2} ; d f(n-1)\right) \leq$

thitung $\leq+t\left(\frac{\alpha}{2} ; d f(n-1)\right)$

$\mathrm{H}_{\mathrm{o}}$ ditolak jika

thitung $<-t\left(\frac{\alpha}{2} ; d f(n-1)\right)$ atau

thitung $>+t\left(\frac{\alpha}{2} ; d f(n-1)\right)$ atau

Sig. $\leq \alpha$

\section{Pengujian}

Uji hipotesis di atas menggunakan uji $t$ dua pihak dengan menggunakan persamaan :

$$
\text { thitung }=\frac{\bar{D}}{\frac{S_{D}}{\sqrt{n}}}
$$

5. Penarikan Kesimpulan

Berdasarkan pengujian dan kriteria pengujian, maka selanjutnya kita tentukan $\mathrm{H}_{\mathrm{o}}$ diterima atau ditolak.

\section{Hasil Dan Pembahasan}

\section{Pelaksanaan Lesson Study}

Pelaksanaan Lesson Study dilaksanakan dalam tujuh pertemuan dengan masing-masing pertemuan meliputi tiga tahap yaitu paln, do dan See. Berikut akan diuraikan secara lebih rinci mengenai kegiatan Lesson Study di Jurusan Teknik Indstri Fakultas Sains dan Teknologi UIN Sultan Syarif Kasim Riau.

Dalam proses pembelajaran setiap awal pembelajaran selalu dimuali dengan berdoa bersama dan mahasiswa mulai berkonsentrasi setelah pembacaan doa bersama.

Berdasarka lembar observasi dan dokumentasi, keaktifan, kemampuan berfikir analitis dan skill keteknikan mahasiswa mengalami peningkatan di setiap pertemuan. Keaktifan mahasiswa terlihat dari perilaku mahasiswa yang sebelumnya sebahagian besar bersifat pasif dan tidak ikut memberikan pendapat, tidak bertanya, tidak mencatat dan tidak memperhatikan dengan baik ketika perkuliahan berlangsung menjadi antusias dan memiliki keberanian yang tinggi untuk ikut memberikan pendapat, bertanya, mencatat, mengamati simulasi dan memperhatikan penjelasan-penjelasan baik dari dosen maupun dari mahaisswa lain ketika perkuliahan berlangsung. Kemampuan analitis mahasiswa yang sebelumnya sangat kurang, seperti ketidak mampuan mahasiswa memberikan alasan, membuat kesimpulan, mengevaluasi kesimpulan dan ketidak mampuan dalam menggunakan data pendukung untuk menjelaskan sesuatu meningkat menjadi memiliki kemampuan dalam memberikan alasan, membuat laporan simulasi, membuat kesimpulan, mengevaluasi kesimpulan dan mampu menggunakan data pendukung untuk menjelaskan sesuatu hal. Skill keteknikan mahasiswa yang sebelumnya masih rendah dimana mahasiswa tidak mampu menggambarkan contoh aplikatif dari materi yang dipelajari meningkat menjadi memiliki kemampuan yang baik untuk menggambarkan dan mengaplikasikan teori yang dipelajari kedalam bentuk karya nyata. 


\section{Data Hasil Pembelajaran}

Data hasil pembelajaran merupakan data hasil tes yang dilakukan secara berkala setiap pertemuan. Data hasil pembelajaran mahasiswa setiap pertemuan dapat disajikan pada Gambar 2.

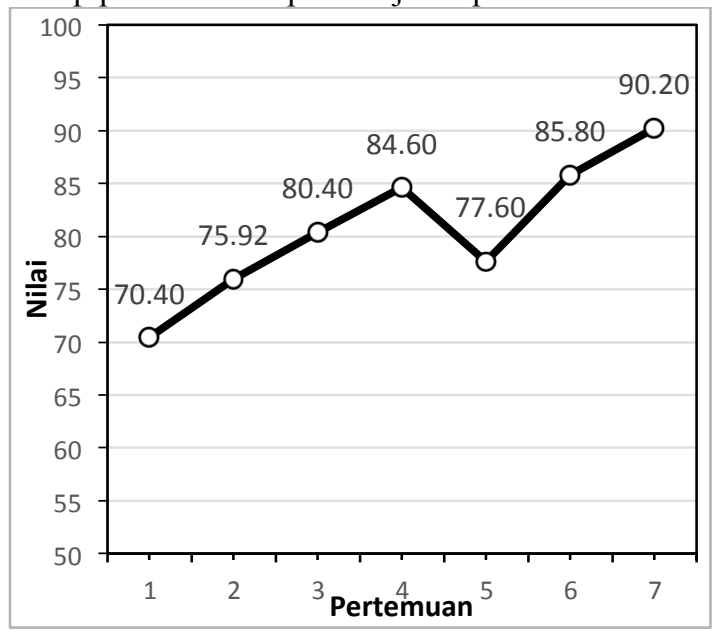

Gambar 2. Grafik Nilai Mahasiswa Setiap Pertemuan

Berdasarkan gambar 2. dapat jelaskan bahwa secara umum nilai hasil pembelajaran mahasiswa mengalami peningkatan mulai dari pertemuan Ke I sampai pada pertemuan ke VII. Meskipun demikian, secara detail tidak setiap pertemuan mengalami peningkatan, seperti halnya terjadi penurunan hasil pembelajaran pada pertemuan ke V. Pertemuan ke V membahas materi mengenai Statika Benda Tegar yang memang merupakan materi yang sedikit lebih rumit dibandingkan dengan materi yang lain. Materi Statika Benda Tegar ini juga memiliki hubungan yang kuat dengan materi pada pertemuan ke VI yaitu materi tentang Konsep Kesetimbangan, dan mahasiswa diharapkan akan lebih memahami materi tersebut setelah pertemuan ke VI.

\section{Data Gain Peningkatan Hasil Belajar Mahasiswa}

Untuk mengukur kriteria peningkatan hasil belajar mahasiswa tersebut dilakukan dengan uji gain. Gain yang digunakan untuk menghitung peningkatan hasil belajar mahasiswa adalah ratarata gain ternormalisasi (normalisasi gain). Data peningkatan hasil belajar mahasiswa melalui implementasi lesson study disajikan dalam tabel 1 dan tabel 2.

Dengan mempertimbangkan hasil Gain, maka dapat diketahui bahwa implementsi lesson study dengan metoda Problem Base Learning yang diterapkan kepada mahasiswa mampu meningkatkan nilai hasil belajar mahasiswa.

Peningkatan nilai hasil belajar mahasiswa setiap pertemuan berada pada kategori rendah sampai kategori sedang $\langle g\rangle<0,3$ sampai dengan $0,3 \leq\langle g\rangle<0,7$, sedangkan peningkatan nilai hasil belajar mahasiswa dari pertemuan-I sampai dengan pertemuan-VII berada pada kategori tinggi $\langle g\rangle \geq 0,7$.

Tabel 1. Peningkatan Hasil Pembelajaran Mahasiswa Setiap Pertemuan

\begin{tabular}{|c|c|c|c|c|c|}
\hline \multicolumn{2}{|r|}{ Pair } & \multirow{2}{*}{$\begin{array}{c}\begin{array}{c}\text { Nilai } \\
\text { Rata-Rata }\end{array} \\
70,40 \\
75,92\end{array}$} & \multirow{2}{*}{$\begin{array}{c}\text { Peningkatan } \\
7,8 \%\end{array}$} & \multirow{2}{*}{$\begin{array}{c}\text { Gain Score } \\
0,186\end{array}$} & \multirow{2}{*}{$\begin{array}{l}\text { Kriteria } \\
\text { Rendah }\end{array}$} \\
\hline Pair 1 & $\begin{array}{l}\text { Pertemuan-I } \\
\text { Pertemuan-II }\end{array}$ & & & & \\
\hline Pair 2 & $\begin{array}{l}\text { Pertemuan-II } \\
\text { Pertemuan-III }\end{array}$ & $\begin{array}{l}75,92 \\
80,40 \\
\end{array}$ & $5,9 \%$ & 0,186 & Rendah \\
\hline Pair 3 & $\begin{array}{l}\text { Pertemuan-III } \\
\text { Pertemuan-IV }\end{array}$ & $\begin{array}{l}80,40 \\
84,60 \\
\end{array}$ & $5,2 \%$ & 0,214 & Rendah \\
\hline Pair 4 & $\begin{array}{l}\text { Pertemuan-IV } \\
\text { Pertemuan V }\end{array}$ & $\begin{array}{l}84,60 \\
77,60 \\
\end{array}$ & $-8,3 \%$ & $-0,455$ & Rendah \\
\hline Pair 5 & $\begin{array}{l}\text { Pertemuan V } \\
\text { Pertemuan VI }\end{array}$ & $\begin{array}{l}77,60 \\
85,80 \\
\end{array}$ & $10,6 \%$ & 0,366 & Sedang \\
\hline Pair 6 & $\begin{array}{l}\text { Pertemuan VI } \\
\text { Pertemuan VII }\end{array}$ & $\begin{array}{l}85,80 \\
91,20\end{array}$ & $6,3 \%$ & 0,380 & Sedang \\
\hline
\end{tabular}

Tabel 2. Peningkatan Hasil Pembelajaran Mahasiswa Pertemuan-I \& Pertemuan-VII

\begin{tabular}{||l|c|c|c|c||}
\hline \multicolumn{1}{|c|}{ Pair } & $\begin{array}{c}\text { Nilai } \\
\text { Rata-Rata }\end{array}$ & Peningkatan & Gain Score & Kriteria \\
\hline \hline Pertemuan-I & $\begin{array}{c}70,40 \\
91,20\end{array}$ & $29,5 \%$ & 0,703 & Tinggi \\
\hline
\end{tabular}




\section{Analisa Data Uji Hipotesis Peningkatan Hasil Belajar Mahasiswa}

Untuk memperkuat analisis peningkatan hasil belajar mahasiswa maka dilakukan uji hipotesis dengan menggunakan metoda paired sample $t$ test atau uji hipotesis data berpasangan. Hasil uji hipotesis peningkatan hasil belajar mahasiswa Mekanika Teknik dengan implementasi lesson study di tampilkan pada tabel 3. sampai dengan tabel 5.

Tabel 3. Paired Samples Correlations

\begin{tabular}{||ll|r|r|r||}
\hline \multicolumn{1}{|c|}{ Pair } & N & Correlation & \multicolumn{1}{c||}{ Sig. } \\
\hline \hline Pair 1 & Pertemuan_I \& Pertemuan_II & 25 & .467 & .019 \\
\hline Pair 2 & Pertemuan_II \& Pertemuan_III & 25 & .618 & .001 \\
\hline Pair 3 & Pertemuan_III \& Pertemuan_IV & 25 & .626 & .001 \\
\hline Pair 4 & Pertemuan_IV \& Pertemuan_V & 25 & -.048 & .819 \\
\hline Pair 5 & Pertemuan_V \& Pertemuan_VI & 25 & .364 & .074 \\
\hline Pair 6 & Pertemuan_VI \&Pertemuan_VII & 25 & .435 & .030 \\
\hline
\end{tabular}

Tabel 3. menunjukkan hubungan antara rata-rata nilai hasil belajar mahasiswa setiap setiap setelah dilakukannya implementasi lesson study. Terlihat bahwa Pair 1 (pertemuan-I \& pertemuan-II), Pair 2 (pertemuan-II \& pertemuanIII), Pair 3 (pertemuan-IV \& pertemuan-V), dan Pair 6 (pertemuan-VI \& pertemuan-VII) memiliki nilai significance (sig.) $<\alpha(0,05)$. Nilai sig. untuk pair 4 (pertemuan-IV \& pertemuan-V) dan pair 5 (pertemuan-V \& pertemuan-VI) memperlihatkan nilai yang berbeda yaitu $>\alpha$ $(0,05)$. Nilai sig. $<\alpha(0,05)$ menunjukkan ada hubungan yang signifikan antara implementasi lesson study terhadap peningkatan nilai hasil belajar mahasiswa, sementara niai sig. $>\alpha(0,05)$ menunjukkan tidak ada hubungan yang signifikan antara implementasi lesson study terhadap peningkatan nilai hasil belajar mahasiswa. Nilai sig. $>\alpha(0,05)$ terjadi pada pair 4 dan pair 5 , hal ini dapat dipahami karena memang pada pertemuan ke 5 terjadi penurunan nilai hasil belajar mahasiswa yang disebabkan oleh bebrapa faktor seperti telah dijelaskan pada pembahasan sebelumnya.

Tabel 4. Paired Sample Test Untuk Setiap Pertemuan

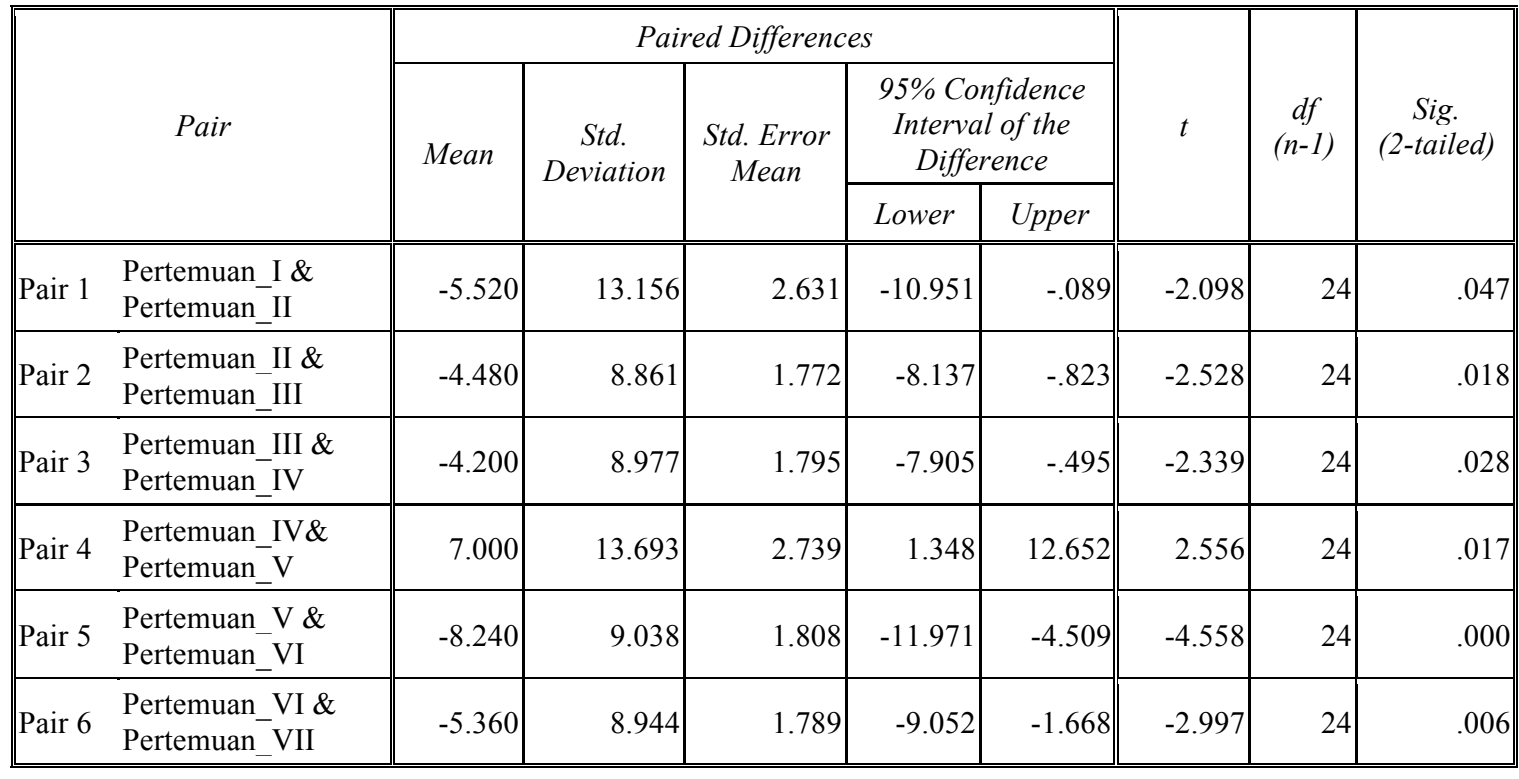


Tabel 5. Paired Sample Test Untuk Pertemuan-I \& Pertemuan-VII

\begin{tabular}{|c|c|c|c|c|c|c|c|c|}
\hline \multirow{3}{*}{ Pair } & \multicolumn{5}{|c|}{ Paired Differences } & \multirow{3}{*}{$t$} & \multirow{3}{*}{$\begin{array}{c}d f \\
(n-1)\end{array}$} & \multirow{3}{*}{$\begin{array}{c}\text { Sig. } \\
\text { (2-tailed) }\end{array}$} \\
\hline & \multirow[t]{2}{*}{ Mean } & \multirow[t]{2}{*}{$\begin{array}{c}\text { Std. } \\
\text { Deviation }\end{array}$} & \multirow[t]{2}{*}{$\begin{array}{l}\text { Std. Error } \\
\quad \text { Mean }\end{array}$} & \multicolumn{2}{|c|}{$\begin{array}{l}\text { 95\% Confidence } \\
\text { Interval of the } \\
\text { Difference }\end{array}$} & & & \\
\hline & & & & Lower & Upper & & & \\
\hline $\begin{array}{l}\text { Pertemuan_I \& } \\
\text { Pertemuan_VII }\end{array}$ & -20.800 & 14.045 & 2.809 & -26.597 & -15.003 & -7.405 & 24 & .000 \\
\hline
\end{tabular}

Berdasarkan tabel 4 dan tabel 5, dapat diinterpretasikan sebagai berikut:

1. Pair 1 (Pertemuan-I \& Pertemuan-II)

Nilai thitung $=-2,098$, nilai $-\mathrm{t}$ tabel $=-2,064$ $t$ hitung $(-2,098)<-t$ tabel $(-2,064)$

$\mathrm{H}_{\mathrm{o}}$ ditolak

Sig. $(0,047)<\alpha(0,05)$

$\mathrm{H}_{\mathrm{o}}$ ditolak

2. Pair 2 (Pertemuan-II \& Pertemuan-III)

Nilai thitung $=-2,528$, nilai $-\mathrm{t}$ tabel $=-2,064$

$t$ hitung $(-2,528)<-t$ tabel $(-2,064)$

$\mathrm{H}_{\mathrm{o}}$ ditolak

Sig. $(0,018)<\alpha(0,05)$

$\mathrm{H}_{\mathrm{o}}$ ditolak

3. Pair 3 (Pertemuan-III \& Pertemuan-IV)

Nilai $t$ hitung $=-2,339$, nilai $-\mathrm{t}$ tabel $=-2,064$ t hitung $(-2,339)<-\mathrm{t}$ tabel $(-2,064)$

$\mathrm{H}_{\mathrm{o}}$ ditolak

Sig. $(0,028)<\alpha(0,05)$

$\mathrm{H}_{\mathrm{o}}$ ditolak

4. Pair 4 (Pertemuan-IV \& Pertemuan V)

Nilai t hitung $=2,556$, nilai $t$ tabel $=2,064$

$\mathrm{t}$ hitung $(2,556)>\mathrm{t}$ tabel $(2,064)$

$\mathrm{H}_{\mathrm{o}}$ ditolak

Sig. $(0,017)<\alpha(0,05)$

$\mathrm{H}_{\mathrm{o}}$ ditolak

5. Pair 5 (Pertemuan-V \& Pertemuan VI)

Nilai thitung $=-4,558$, nilai $-\mathrm{t}$ tabel $=-2,064$

t hitung $(-4,558)<-\mathrm{t}$ tabel $(-2,064)$

$\mathrm{H}_{\mathrm{o}}$ ditolak

Sig. $(0,000)<\alpha(0,05)$

$\mathrm{H}_{\mathrm{o}}$ ditolak

6. Pair 6 (Pertemuan-VI \& Pertemuan VII)

Nilai t hitung $=-2,366$, nilai $-\mathrm{t}$ tabel $=-2,064$ thitung $(-2,977)<-t$ tabel $(-2,064)$

$\mathrm{H}_{\mathrm{o}}$ ditolak

Sig. $(0,006)<\alpha(0,05)$

$\mathrm{H}_{\mathrm{o}}$ ditolak

7. Pair Pertemuan-I \& Pertemuan VII

Nilai thitung $=-7,405$, nilai $-t$ tabel $=-2,064$

t hitung $(-7,405)<-$ t tabel $(-2,064)$

$\mathrm{H}_{\mathrm{o}}$ ditolak
Sig. $(0,000)<\alpha(0,05)$

$\mathrm{H}_{\mathrm{o}}$ ditolak

Berdasarkan interpretasi data dapat diambil keputusan karena Sig. $<\alpha$ dan/ atau $\mathrm{t}$ hitung $<-t$ tabel maka keputusannya adalah $\mathrm{H}_{\mathrm{o}}$ ditolak sehingga $\mathrm{H}_{1}$ diterima. Jadi dapat di simpulkan dengan tingkat signifikansi 5\% $(\alpha=0,05)$ terdapat peningkatan yang signifikan terhadap nilai hasil belajar mahasiswa dengan implementasi lesson study.

Secara keseluruhan hasil pengolahan dan analisa data memperlihatkan adanya peningkatan hasil belajar mahasiswa Mekanika Teknik Kelas IIIB Jurusan Teknik Industri Fakultas Sains dan Teknologi UIN Sultan Syarif Kasim Riau dengan implementasi lesson study. Meskipun kriteria nilai Gain dan hubungan korelasi untuk setiap pertemuan masih menunjukkan nilai yang berada pada kriteria rendah dan sedang $(\langle g\rangle<0,3$ sampai dengan $0,3 \leq\langle g\rangle<0,7)$ tetapi nilai gain dari pertemuan-I sampai dengan Pertemuan-VII menunjukkan nilai yang berada pada kriteria yang tinggi $(\langle g\rangle \geq 0,7)$.

\section{Kesimpulan}

Berdasarkan pengolahan dan analisa data pelaksanaan pembelajaran dengan implementasi lesson study yang telah dilakukan terhadap mahasiswa Mekanika Teknik selama 7 pertemuan (setengah semester), maka dapat di simpulkan bahwa:

1. Melalui implementasi lesson study dengan metoda pembelajaran Problem Base Learning dalam mata kuliah Mekanika Teknik, proses pembelajaran berupa keaktifan, kemampuan berfikir analitis dan skill keteknikan mahasiswa dapat menigkat dengan baik. Keaktifan mahasiswa terlihat dari perilaku sebahagian besar mahasiswa yang antusias dan memiliki keberanian yang 
tinggi untuk ikut memberikan pendapat, bertanya, mencatat, mengamati simulasi dan memperhatikan penjelasan-penjelasan ketika perkuliahan berlangsung. Kemampuan analitis mahasiswa terlihat dari perilaku mahasiswa yang memiliki kemampuan dalam memberikan alasan, membuat laporan simulasi, membuat kesimpulan, mengevaluasi kesimpulan dan mampu menggunakan data pendukung untuk menjelaskan sesuatu hal. Skill keteknikan mahasiswa terlihat dari perilaku mahasiswa yang mampu menggambarkan dan mengaplikasikan teori yang dipelajari kedalam bentuk karya nyata.

2. Melalui implementasi lesson study dengan metoda pembelajaran Problem Base Learning dalam mata kuliah Mekanika Teknik mampu memberikan dampak terhadap peningkatan hasil pembelajaran berupa nilai mahasiswa dengan baik. Peningkatan nilai hasil pembelajaran mahasiswa setiap pertemuan termasuk dalam kategori sedang yaitu berkisar antara 5,1\% s/d 10,6\% dengan Gain 0,186 s/d 0,380. Akan tetapi jika dibandingkan antara Pertemuan-I dengan Pertemuan-VII peningkatan nilai hasil pembelajaran mahasiswa berada dalam kategori tinggi yaitu 29,5\% dengan Gain 0,703. Dari hasil uji hipotesis dengan tingkat signifikansi 5\% $(\alpha=0,05)$ menunjukkan terdapat peningkatan yang signifikan terhadap nilai hasil belajar mahasiswa dengan implementasi lesson study disetiap pertemuan hal ini dibuktikan dengan nilai Sig. $<\alpha$ atau $\mathrm{t}$ hitung $<-\mathrm{t}$ tabel. Nilai Sig. berkisar antara $0,00 \mathrm{~s} / \mathrm{d} \quad 0,047$ sementara nilai $\alpha=0,05$. Nilai $t$ hitung berkisar anatara $\quad-4,588 \mathrm{~s} / \mathrm{d} \quad-2,098$, sementara nilat $\mathrm{t}$ tabel $=-2,064$.

\section{Saran}

Berdasarkan hasil implementasi dari lesson study yang telah peneliti lakukan bebarapa saran dapat di sampaikan sebagai beriukut:

1. Lesson Study sebaiknya dilaksanakan secara berkelanjutan sehingga proses pembelajaran berupa keaktifan dan kemampuan berfikir analitis serta nilai hasil pembelajaran mahasiswa dapat meningkat dengan kriteria sangat baik.

2. Perlu dilakukan pelatihan atau workshop mengenai lesson study dalam rangka meningkatkan pemahaman dan keterampilan tim dalam palaksanaan lesson study sehingga pelaksanaan lesson study bisa berjalan dengan maksimal.
3. Karena lesson study membutuhkan alokasi waktu yang lebih lama maka perlu adanya penambahan jam pelajaran mata kuliah agar pelaksanaan lesson study dapat dilakukan dengan baik.

4. Untuk melengkapi dan mendukung pelaksanaan PBL, sebaiknya fasilitas dan media pembelajaran harus tersedia dengan baik agar pelaksanaan lesson study lebih maksimal.

\section{Daftar Pustaka}

[1] Amir, M. Taufik. (2009). Inovasi Pendidikan Melalui Problem Based Learning. Jakarta : Penerbit Kencana

[2] Arends, Richard. I. (2008). Belajar untuk mengajar. Edisi ke tujuh alih bahasa oleh helly prayitno dan sri mulyantani prayitnodari judul learning to teach. Seven edition. Yogyakarta : Penerbit Pustaka Pelajar.

[3] Arikunto, Suharsimi. (2002). Dasar-Dasar Evaluasi Pendidikan. Jakarta : Penerbit Bumi Aksara

[4] Arikunto, A. 1998. Prosedur Penelitian: Suatu Pendekatan Praktek. Jakarta: PT.Rineka Cipta

[5] Barrows, H. S. (1996). Problem-based learning in medicine and beyond: A brief overview. In L. Wilkerson \& H. Gilselaers (eds.), Bringing problem-based learning to higher education: Theory and practice. San Franscisco, CA: Jossey-Bass Inc

[6] Barrows, H. S. Tamblyn, R. M . (1980). Problem-based learning An Aproach to Medical Education. New York: Springer Publishing Company

[7] Direktorat Ketenagaan, Direktorat Jendral Pendidikan Tinggi, Departemen Pendidikan Nasional, 2008. Panduan Pelaksanaan Lesson Study di LPTK (Lesson Study Dissemination Program For Strengthening Teacher Education in Indonesia LEDIPSTI).

[8] Hake, Richard. R . (1999). Analyzing Change/Gain Score. Dept. of Physics, Indiana University, Woodland Hills, CA, 91367 USA

[9] Ibrahim, M dan Nur, M. 2005. Pengajaran Berdasarkan Masalah. Surabaya: Penerbit University Press.

[10] Sugiyono. 2005. Statistika untuk Penelitian. Bandung: ALFABETA. 